\title{
Acute and Subacute Toxicity Studies of the Combination of the Aqueous Extracts of Trunk Bark of Musanga cecropioides R. Br. (Cecropiaceae) and Fruits of Picralima nitida (Stapf) T. Durand \& H. Durand (Apocynaceae)
}

Tankeu Séverin Elisée ${ }^{1}$, Yinyang Jacques ${ }^{2}$, Bamal Hans-Denis ${ }^{2}$, Mvogo Ottou Patrice Brice ${ }^{1}$, Nkoo Henry Julien Moïse ${ }^{2}$, Ngouondjou Foze Teclaire ${ }^{1}$, Ngoule Charles Christian ${ }^{2}$, Ngene Jean Pierre ${ }^{2}$, Kidik Pouka Cathérine ${ }^{2}$, Etame Loe Gisèle Marguerite ${ }^{2}$, Dibong Siegfried Didier ${ }^{1,2,3 *}$, Claus Jacob ${ }^{3}$

${ }^{1}$ Department of Plant Biology, Faculty of Science, University of Douala, P.O. Box 24157 Douala, Cameroon

${ }^{2}$ Department of Pharmaceutical Sciences, Faculty of Medicine and Pharmaceutical Sciences, University of Douala, P.O. Box 2701 Douala, Cameroon

${ }^{3}$ Division of Bioorganic Chemistry, School of Pharmacy, Saarland University, Campus B2 1, Raum 1.14, D-66123, Saarbrücken, Germany

DOI: $10.36348 /$ simps.2020.v06i04.002

| Received: 27.03.2020 | Accepted: 03.04.2020 | Published: 07.04.2020

*Corresponding author: Dibong Siegfried Didier

\section{Abstract}

The majority of plants used in traditional medicine can have toxic effects. Two hundred grams of vegetable powder of each species were macerated, then filtered under vacuum on a Büchner. Tests for the detection of large groups of phytochemicals were carried out. Microbiological quality control has aimed mainly at Salmonella, yeasts and molds, total coliforms and fecal coliforms. The study of acute toxicity was conducted according to guideline 423 of the OECD protocol and subacute toxicity was studied from guideline 407 of the OECD. The blood samples were taken from the fasted rats and under anesthesia with diethyl ether. The hematological parameters were measured by the Medonic (Beckman coulteur-USA-). The masses obtained after drying the macerate in an oven at $50{ }^{\circ} \mathrm{C}$ were $28 \mathrm{~g}$ and $9.3 \mathrm{~g}$ respectively for Picralima nitida and Musanga cecropioides with respective yields of $14 \%$ and $4.65 \%$. The tests for microbial germs likely to reveal the contamination of the extracts were negative. There were no anomalies in the parameters studied during acute toxicity, except for the aggressiveness of rats during the first day. No deaths have been recorded. The $\mathrm{LD}_{50}$ is therefore greater than $5000 \mathrm{mg} / \mathrm{Kg}$. After twenty-eight days of observation during the study of subacute toxicity, variations in numerous parameters studied were observed in different batches. The average body weights of rats in all batches increased during the observation period. Analysis of the biochemical parameters of the rats' blood showed that many parameters were higher in the control group than in the treated groups.

Keywords: Acute toxicity, subacute toxicity, Picralima nitida, Musanga cecropioides.

Copyright @ 2020: This is an open-access article distributed under the terms of the Creative Commons Attribution license which permits unrestricted use, distribution, and reproduction in any medium for non-commercial use (NonCommercial, or CC-BY-NC) provided the original author and source are credited.

\section{INTRODUCTION}

Cameroon is an undisputed potential of biodiversity because of the diversity and richness of its flora. In addition to their role in the balance of ecosystems, plants provide humans with natural resources essential for their survival and development. Plants contribute to food security and primary health care in almost $80 \%$ of the population of developing countries [1]. In addition, despite the advent of generic drugs, many treatments remain financially inaccessible to economically disadvantaged populations who continue to constantly turn to bioactive molecules in nature to seek essential remedies that are gentle, more effective and with few side effects. The ethnobotanical approach, which is therefore the study of plants in relation to the cultures of human populations, makes it possible to identify traditional remedies for the management of many diseases. As a result, many authors have emphasized this science and studies in different regions, thereby showing that the use of plants to treat chronic and microbial diseases is widespread [27]. Some of these plants include: Picralima nitida, Catharanthus roseus, Senna occidentalis, Rauwolfia vomitoria, Tamarindus indica, Combretum micranthum, Guiera senegalensis, Euphorbia hirta, Allium sativum, Hibiscus sabdarifa [8-10]. In the field of pharmacology, traditional plant-based knowledge has become a recognized tool in the search for new molecules for the production of drugs and other pharmaceutical products [11]. However, many plant species have their own toxicity, direct or indirect, which is necessary to determine before any therapeutic or commercial use. For this purpose, the perfect knowledge of the metabolite constituents of plants as 
well as the related toxicity prove to be necessary for an adequate use in the formulation of the Improved Traditional Medicines and all other related products. Toxicity is defined as all the harmful effects including morphological and functional lesions in a living organism, caused by a substance introduced in a relatively high single dose or in small doses that are repeated for a long time [12]. The acute toxicity study consists in observing the physiological parameters after administration of a single strong dose or of several close doses of the active substance or substances contained in a medicine. It manifests quickly, if not immediately, after administration. The term acute oral toxicity is most often used in connection with the determination of lethality. The subacute toxicity study of a substance is the set of pharmacological tests that determine the degree of harmfulness of the substance in order to regulate its use. The action of a toxic substance is evaluated according to parameters such as its mode of administration (oral, intravenous, intraperitoneal), the dose administered, the mortality rate observed, the weight change, the histology of certain organs and changes in certain biochemical parameters of the blood called toxicity markers (total cholesterols, bilirubin, creatinine, urea). The aim of the research was to study acute and subacute toxicity of the combination of aqueous trunk bark extracts of Musanga cecropioides R. Br. (Cecropiaceae) and the fruits of Picralima nitida (Stapf) T. Durand \& H. Durand (Apocynaceae). The specific objectives were to: (1) calculate extraction yield of the samples, (2) realize microbiological control of extracts, (3) determine various extracts groups of molecules and (4) assess acute and subacute toxicities of the combination of the extracts.

\section{Materials ANd Methods MATERIALS}

The biological material was composed of plant and animal material. The plant material consisted of the trunk bark of Musanga cecropioides and the fruits of $P$. nitida, which were collected in August 2017, in a forest in the locality of Logbadjeck, Department of SanagaMaritime, Littoral region, Cameroon and from a plantation in Nkongsamba, Department of Moungo, Littoral region, Cameroon, respectively. Animal material consisted of white female albino rats of the Wistar strain.

The technical material was made up of extraction material, phytochemical screening material, toxicology study material, glassware, consumables, reagents and solvents.

\section{METHODOLOGY \\ Extraction}

The plant organs used were washed under a continuous stream of water, cut into small pieces and dried in an oven at $50{ }^{\circ} \mathrm{C}$ for 10 days, then pulverized with a grinder [13]. The crude extracts were obtained by extraction with distilled water as a solvent [13]. Two hundred grams $(200 \mathrm{~g})$ of vegetable powder of each species were macerated separately in $1 \mathrm{~L}$ of water for $48 \mathrm{H}$, then filtered under vacuum on a Büchner. The crude aqueous extracts obtained were evaporated in an oven [14]. The extraction yield was calculated relatively to the weight of dry vegetable matter according to the formula:

\section{Mass of the extract obtained \\ $E Y=$ \\ Initial powder mass

\section{Microbiological Control of Extracts}

The quality control of extracts concerning microbiology was done according to the standards established by the European Pharmacopoeia $(\mathrm{PhEu})$ [15]. Therefore, the following germs were chosen: Salmonella, yeasts and molds, total coliforms (TC) and faecal coliforms (FC).

\section{Preparation of samples for microbiological examination}

A mixture of $10 \mathrm{~g}$ of powder, representative of the test sample, and $90 \mathrm{~mL}$ of Buffered Peptone Water (BPW) was made with a measurement uncertainty of \pm $5 \%$, and homogenized for $5 \mathrm{~min}$. Serial 10-fold dilutions were made 45 min after preparing the mother suspension. Each suspension was diluted in BPW and vortexed for 5-10 s.

\section{Total coliform count}

The principle was that of deep plating on Mac Conkey agar described elsewhere [15]. Petri dishes were inoculated with $1 \mathrm{~mL}$ of the mother suspension and the successive dilutions. Mac Conkey agar was added into the plates and homogenized so as to allow the incorporation of the product in the medium over the whole plate, with a negative control. A second layer of the same agar was added to the solidified medium and then left to solidify. The plates were incubated at $37 \pm 1$ ${ }^{\circ} \mathrm{C}$ for $24 \pm 2 \mathrm{H}$. Red colonies surrounded by an opaque halo were observed with diameters $\geq 0.5 \mathrm{~mm}$.

\section{Total Yeast and Mold Count}

The principle was that of deep sowing on Sabouraud agar described elsewhere [15]. Petri dishes were inoculated with $1 \mathrm{ml}$ of the mother suspension and the successive dilutions. Sabouraud agar was added into the plates and homogenized so as to allow the incorporation of the product in the medium over the 
whole plate, with a negative control. A second layer of the same agar was added to the solidified medium and then left to solidify. The plates were incubated at $25 \pm 1$ ${ }^{\circ} \mathrm{C}$ for $72 \pm 2 \mathrm{H}$, and in some necessary cases for $110 \pm$ $2 \mathrm{H}$. White colonies were observed.

\section{Search for Salmonella}

The powder to be diagnosed $(25 \mathrm{~g})$ was added to $225 \mathrm{~mL}$ of $\mathrm{BPW}$ in a sterile sachet. The suspension was incubated at $37^{\circ} \mathrm{C}$ for $18 \pm 2 \mathrm{H}$ to obtain Culture A. A 10-fold dilution of Culture A was made in Buffer Serum (BS) and incubated at $43{ }^{\circ} \mathrm{C}$ for 18 to $24 \mathrm{H}$ to obtain Culture B. A Petri dish containing Hektoen agar was inoculated with Culture B, to allow the development of well-isolated colonies. The inverted plate was incubated at $37{ }^{\circ} \mathrm{C}$ for $24 \pm 3 \mathrm{H}$ and then examined for the presence of typical Salmonella colonies, as well as atypical colonies likely to be Salmonella.

\section{Confirmation}

For confirmation, a minimum of one colony considered characteristic or suspect, was taken from each plate and inoculated on the surface of previously dried nutritive agar plates, so as to allow the development of well-isolated colonies. The plates were incubated at $37 \pm 1{ }^{\circ} \mathrm{C}$ for $24 \pm 3 \mathrm{H}$. Biochemical confirmation was performed with pure cultures using Vitek identification galleries. Serological confirmation of pure cultures consisted in the search for the presence of Salmonella $\mathrm{O}, \mathrm{Vi}$ or $\mathrm{H}$ antigens and was carried out by agglutination on a slide with the appropriate sera, after elimination of the self-agglutinating strains.

\section{Phytochemical screening}

The tests for detecting large groups of phytochemicals were carried out as described elsewhere, on five residues obtained from ethanol, methanol, ethyl acetate, hexane and water as extraction solvent $[16,17]$.

\section{Sterol and polyterpenes test}

The sterols and the polyterpenes were detected in the aqueous residue using the Liebermann reaction. An aliquot of residue was dissolved hot in $1 \mathrm{~mL}$ of acetic anhydride in a capsule, then taken up in a test tube into which was poured $0.5 \mathrm{~mL}$ of concentrated sulfuric acid $\left(\mathrm{H}_{2} \mathrm{SO}_{4}\right)$. The appearance of a purple color that turned blue and then green indicated a positive reaction.

\section{Flavonoids test}

The flavonoids were detected in the methanolic residue by its reaction to cyanidine. To an aliquot of residue dissolved in $5 \mathrm{~mL}$ of hydrochloric methanol (v/v) were added two to three shavings of magnesium (or 30 to $50 \mathrm{mg}$ of zinc powder) and a few drops of isopentanol. The appearance of an intense pink-orange or purplish color (red or red-orange with Zinc) indicated a positive reaction.

\section{Saponin test}

The saponins were detected in the aqueous residue by the foam test, then their presence was confirmed by the blood test and by the determination of the optical density (OD). The residues were taken up in $5 \mathrm{~mL}$ of distilled water, then introduced into a test tube. The test tube was shaken vigorously. The formation of a foam (height greater than $1 \mathrm{~cm}$ ) stable, persisting for 1 hour indicated the abundant presence of saponins. The blood test could also be performed on the aqueous extract. A few drops of aqueous extract were added to a test tube containing $2 \mathrm{ml}$ of fresh animal blood dissolved in a physiological solution $(0.9 \%$ aqueous $\mathrm{NaCl}$ solution). Observations of discoloration compared to a control tube indicated a positive test. Blood solution ( $1 \mathrm{~mL}$ of blood in $25 \mathrm{~mL}$ of isotonic solution) was introduced into 3 test tubes. One of the tubes served as a control. In each of the two remaining, 5 and 10 drops of extracts to be tested were added respectively. After homogenization, the content of the test tubes was centrifuged for $10 \mathrm{~min}$ at $2000 \mathrm{rpm}$, then the OD of each supernatant removed was measured using a colorimeter (wavelength $420 \mathrm{~nm}$ ).

\section{Alkaloids test}

The alkaloids were detected in the ethanolic and methanolic residue with the Dragendorff and Burchard reagents (precipitation reagents): $0.1 \mathrm{~g}$ of residue was taken up in $6 \mathrm{~mL}$ of $60 \%$ ethanol, then distributed in 2 test tubes. In the first tube, 2 drops of Dragendorff reagent were added. The appearance of an orange-red or brown-reddish precipitate indicated a positive test. In the second tube, 2 drops of Burchard reagent were added. The appearance of a brown precipitate indicated a positive test.

\section{Coumarin Detection}

Coumarins were highlighted in the aqueous residue by the reaction on the lactonic cycle. $2 \mathrm{~mL}$ of methanolic solution obtained from each residue were introduced into 2 test tubes. $0.5 \mathrm{ml}$ of $10 \% \mathrm{NaOH}$ was added to one of the test tubes, then the test tubes were heated in a water bath until boiling. After cooling, $4 \mathrm{~mL}$ of distilled water were added to each test tube. The reaction was positive when the liquid in the test tube to which the alkaline solution was added was transparent or more transparent than the liquid in the control test tube (without alkaline solution). The acidification of the transparent solution with a few drops of concentrated $\mathrm{HCl}$ caused the loss of the yellow color, a precipitate formed.

\section{Detection of Tannins}

True tannins were brought to light in the presence of concentrated HCL: to an aliquot of residue taken up in $2 \mathrm{~mL}$ of methanol, a few drops of 
concentrated $\mathrm{HCl}$ were added, the whole was heated in a boiling bain-marie. The formation of a red precipitate indicated a positive test. The detection of tannoids was carried out in the residues. A few drops of a $2 \%$ methanolic ferric trichloride solution were added to the filtrates of the saturated sodium ethanoate reaction masses. The reaction was positive when a blue-black hue appeared.

\section{Detection of Reducing Sugars}

The reducing sugars were highlighted in the crude extracts of the two plants by the Fehling reagent, then their presence was confirmed by the Tollens test. To perform the Fehling test, $5 \mathrm{~mL}$ of Fehling liquor was added to $5 \mathrm{~mL}$ of crude extract. The formation of a brick-red precipitate after 2 to $3 \mathrm{~min}$ of heating in a water bath at $70{ }^{\circ} \mathrm{C}$ indicated a positive reaction. The detection of reducing sugars by the Tollens test consisted in adding $5 \mathrm{~mL}$ of the Tollens reagent to $5 \mathrm{~mL}$ of crude extract. The formation of a silver mirror after a few minutes indicated a positive reaction.

\section{Acute and subacute toxicities of the combination of extracts}

Acute toxicity experiment was conducted according to guideline 423 of the OECD protocol [18]. Ten-week-old female Wistar rats were fasted over the night preceding the experiment from 8 p.m. to 8 a.m. Four (4) batches of six (6) randomized rats received the combination of the aqueous extracts of the fruits of $P$. nitida and the bark of $M$. cecropioides, at doses of 50, 300,2000 and $5000 \mathrm{mg} / \mathrm{Kg}$ body weight, respectively. The control batch received distilled water. Once treated, the animals were observed for $2 \mathrm{H}$ after the administration of the extract. They were then fed and observed after $4,8 \mathrm{H}$ and then 14 days during which the symptoms of intoxication (modification of the coat, motility, tremors, grooming, breathing, sensitivity to noise, as well as deaths) were noted. The dead rats in each batch were counted for the determination of the $\mathrm{LD}_{50}$. The extract was administered to animals orally.

Subacute toxicity has been studied as per OECD Guideline 407 with slight modifications [19]. Eight-week-old adult, Wistar albino, male and female rats were divided into three experimental batches of six (6) animals each, three males and three females. They were fasted the night before the experiment from 8 p.m. to 8 a.m. The limit tests were carried out at a dose of $1000 \mathrm{mg} / \mathrm{Kg}$ on one batch, while on another, the subacute toxicity tests were carried out at a dose of 171 $\mathrm{mg} / \mathrm{Kg}$, corresponding to the dose of the traditional health practitioner. The control batch received distilled water. The administrations continued for 28 days with 6 days of administration out of seven per week. After 28 days, the organs removed: kidneys, liver, lungs, heart, pancreas were rinsed with $0.9 \%$ saline solution (physiological solution), then observed in situ and weighed.

\section{Blood samples}

The blood samples were taken from the fasted rats and under anesthesia with diethyl ether. They were performed at the chinstrap. The blood sample was collected in three types of tubes (heparin tubes, EDTA tubes, and dry tubes). The EDTA tubes and the dry tubes were intended for hematological analyzes. The heparinized tubes were centrifuged at $4000 \mathrm{rpm}$ for 10 min and the serum obtained was stored at $-20{ }^{\circ} \mathrm{C}$ for blood biochemistry analyzes.

\section{Biochemical examinations}

The following serum parameters : Glucose (Glu), Creatinine (Creatine), Uric acid (UA), Total cholesterol (Chol T), Total triglycerides (TG), Glutamate Oxolo-acetate Transaminase (GOT), Glutamate Pyruvate Transaminase (GPT), were measured by enzymatic methods. These assays were carried out at the Hematology and Pathology Laboratory of Douala General Hospital.

\section{Hematological examinations}

The hematological parameters for the blood count formula (SNF) were : white blood cell (WBC) count, red blood cell (RBC) count, hemoglobin $(\mathrm{Hb})$ count, hematocrit (Hct), mean corpuscular volume (MCV), mean corpuscular hemoglobin $(\mathrm{MCH})$, mean corpuscular hemoglobin Concentration (MCHC), platelet (PLT) count and neutrophil (N) count. These parameters were carried out by Medonic (Beckman Coulter, USA) at the Hematology and Pathology Laboratory of Douala General Hospital.

\section{STATISTICAL ANALYZES}

Means, standard deviations, curves and histograms were obtained with the use of Microsoft Excel version 2016. ANOVA tests were applied at the $5 \%$ threshold to establish the differences between the values of the parameters observed, using GraphpadInstat software.

\section{ReSULTS \\ Calculation of extraction yield}

The aqueous extracts were prepared from 200 $\mathrm{g}$ of $P$. nitida fruit powder and $200 \mathrm{~g}$ of Musanga cecropioides bark powder by maceration, with yields of $14 \%(28 \mathrm{~g})$ and $4.65 \%(9.3 \mathrm{~g})$, respectively, after drying in an oven at $50{ }^{\circ} \mathrm{C}$ (Table-1). 
Tankeu Séverin Elisée et al; Saudi J Med Pharm Sci, April., 2020; 6(4): 334-348

Table-1: Extraction efficiency of the powders used

\begin{tabular}{|l|l|l|l|}
\hline Species studied & Mass of macerated powders & Mass of crude extract obtained & Extraction efficiency \\
\hline Picralima nitida & $200 \mathrm{~g}$ & $28 \mathrm{~g}$ & $14 \%$ \\
\hline Musanga cecropioides & $200 \mathrm{~g}$ & $9.3 \mathrm{~g}$ & $4.65 \%$ \\
\hline
\end{tabular}

\section{Realization of microbiological control of extracts}

Both plants' extracts were subjected to microbiological control before their use in the various activities. The tests for microbial germs likely to reveal the contamination of the extracts were negative. The extracts were therefore proven to be of high quality and could be used for the rest of the study.

\section{Determination of various groups of molecules}

The phytochemical study of extract from the bark of Musanga cecropioides revealed the presence of various groups of molecules. The tests for alkaloids, sterols, terpenes and coumarins were positive but showed low concentrations with the hexane extract. With the ethyl acetate extract, the test for alkaloids was positive with medium concentrations while the tests for phenols and tannins were positive with low concentrations. The water extract revealed the presence of alkaloids and saponins at high concentrations, phenols and flavonoids at medium concentrations and then sterols and reducing sugars at low concentrations. In the ethanol extract, the test for alkaloids was positive with medium concentrations while the tests for phenol, tannin, flavonoid and reducing sugar were positive with low concentrations. In the methanol extract, the tests for flavonoids and saponins were positive with high concentrations, while the tests for sterols and reducing sugars were positive with medium concentrations and those for terpenes, phenols, coumarins, flavonoids, and tannins were found to be positive with low concentrations. However, it should be noted that only the tests for alkaloids were found to be positive with all extraction solvents while the tests for anthraquinones and anthocyanins were found to be negative (Tabl-2).

Table-2: Phytochemical study of Musanga cecropioides extract

\begin{tabular}{|l|l|l|l|l|l|}
\hline $\begin{array}{l}\text { Secondary } \\
\text { metabolites }\end{array}$ & $\begin{array}{l}\text { Hexane } \\
\text { extract }\end{array}$ & $\begin{array}{l}\text { Ethyl acetate } \\
\text { extract }\end{array}$ & $\begin{array}{l}\text { Water } \\
\text { extract }\end{array}$ & $\begin{array}{l}\text { Ethanol } \\
\text { extract }\end{array}$ & $\begin{array}{l}\text { Methanol } \\
\text { extract }\end{array}$ \\
\hline alkaloids & + & ++ & +++ & ++ & +++ \\
\hline sterols & + & - & + & - & ++ \\
\hline terpenes & + & - & - & - & + \\
\hline phenols & - & + & ++ & + & + \\
\hline coumarins & + & - & - & - & + \\
\hline flavonoids & - & - & ++ & + & + \\
\hline tannins & - & + & - & + & + \\
\hline saponins & - & - & +++ & - & +++ \\
\hline Reducing sugars & - & - & + & + & ++ \\
\hline anthraquinone & - & - & - & - & - \\
\hline anthocyanins & - & - & - & - & - \\
\hline
\end{tabular}

$(+++)=$ positive test $($ high concentration $) ;(++)=$ positive test $($ average concentration $) ;(+)=$ positive test $($ low concentration $) ;(-)=$ negative test.

The phytochemical study of $P$. nitida extract was carried out with fruit extracts. The tests for sterol and flavonoid were positive with the hexane extract at medium concentrations while the test for saponin was positive at low concentrations. With the ethyl acetate extract, all tests were negative, except for the saponins, which showed average concentrations. The aqueous extract showed the presence of phenols, flavonoids and saponins at high concentrations, sterols at medium concentrations, alkaloids, and coumarins at low concentrations. With the ethanol extract, the tests for saponins and flavonoids were positive, and revealed high and medium concentrations respectively, while those for alkaloids, phenols, tannins, reducing sugars were positive with low concentrations. With the methanol extract, the tests for flavonoids and saponins were positive with high concentrations, while the tests for sterols, phenols and reducing sugars were positive with medium concentrations and those for tri-terpenes and tannins were found to be positive with low concentrations. However, it should be noted that only the tests for saponins were positive with all the solvents while those for anthraquinones and anthocyanins were negative (Table3). 
Tankeu Séverin Elisée et al; Saudi J Med Pharm Sci, April., 2020; 6(4): 334-348

Table-3: Phytochemical study of Picralima nitida extract

\begin{tabular}{|l|l|l|l|l|l|}
\hline $\begin{array}{l}\text { Secondary } \\
\text { metabolites }\end{array}$ & $\begin{array}{l}\text { Hexane } \\
\text { extract }\end{array}$ & $\begin{array}{l}\text { Ethyl acetate } \\
\text { extract }\end{array}$ & $\begin{array}{l}\text { Water } \\
\text { extract }\end{array}$ & $\begin{array}{l}\text { Ethanol } \\
\text { extract }\end{array}$ & $\begin{array}{l}\text { Methanol } \\
\text { extract }\end{array}$ \\
\hline alkaloids & - & - & + & + & - \\
\hline sterols & ++ & - & ++ & - & ++ \\
\hline terpenes & - & - & - & - & + \\
\hline phenols & - & - & +++ & + & ++ \\
\hline coumarins & - & - & + & - & - \\
\hline flavonoids & ++ & - & +++ & ++ & +++ \\
\hline tannins & - & - & - & + & + \\
\hline saponins & + & ++ & +++ & +++ & +++ \\
\hline Reducing sugars & - & - & - & + & ++ \\
\hline anthraquinone & - & - & - & - & - \\
\hline anthocyanins & - & - & - & - & - \\
\hline
\end{tabular}

$(+++)=$ positive test $($ high concentration $) ;(++)=$ positive test $($ average concentration $) ;(+)=$ positive test $($ low concentration $) ;(-)=$ negative test.

\section{Assessment of acute and subacute toxicities of the combination of extracts}

The acute toxicity study focused on the observation of physiological changes in white albino rats of the Wistar strain. The combination of the extracts of $P$. nitida and $M$. cecropioides in the proportions $50: 50 \%$ was administered to the rats and the observation was made during the first 2,4 and $8 \mathrm{H}$ (DO), then once every day, for 14 days (D1 towards D14) after administration. At the end of the 14 days, there were no anomalies in the parameters studied, except for the aggressiveness of the rats during the first day. No deaths were recorded. The LD50 is therefore greater than 5,000 $\mathrm{mg} / \mathrm{Kg}$ (Table-4).

\section{Acute toxicity of the combination of extracts}

Table-4: Acute toxicity of the combination of extracts

\begin{tabular}{|c|c|c|c|c|c|c|c|c|c|c|c|c|c|c|c|c|c|c|}
\hline \multirow{2}{*}{$\begin{array}{l}\text { Parameters } \\
\text { observed }\end{array}$} & \multicolumn{18}{|c|}{ Study period } \\
\hline & $1 \mathrm{~h}$ & $2 \mathrm{~h}$ & $4 \mathrm{~h}$ & $\mathbf{8 h}$ & D1 & D2 & D3 & D4 & D5 & D6 & D7 & D8 & D9 & D10 & D11 & D12 & D13 & D14 \\
\hline motility & $\mathrm{N}$ & $\mathrm{N}$ & $\mathrm{N}$ & $\mathrm{N}$ & $\mathrm{N}$ & $\mathrm{N}$ & $\mathrm{N}$ & $\mathrm{N}$ & $\mathrm{N}$ & $\mathrm{N}$ & $\mathrm{N}$ & $\mathrm{N}$ & $\mathrm{N}$ & $\mathrm{N}$ & $\mathrm{N}$ & $\mathrm{N}$ & $\mathrm{N}$ & $\mathrm{N}$ \\
\hline coat & $\mathrm{N}$ & $\mathrm{N}$ & $\mathrm{N}$ & $\mathrm{N}$ & $\mathrm{N}$ & $\mathrm{N}$ & $\mathrm{N}$ & $\mathrm{N}$ & $\mathrm{N}$ & $\mathrm{N}$ & $\mathrm{N}$ & $\mathrm{N}$ & $\mathrm{N}$ & $\mathrm{N}$ & $\mathrm{N}$ & $\mathrm{N}$ & $\mathrm{N}$ & $\mathrm{N}$ \\
\hline tremors & Abs & Abs & Abs & $\mathrm{Abs}$ & Abs & Abs & Abs & Abs & Abs & $\mathrm{Abs}$ & Abs & Abs & Abs & Abs & Abs & Abs & Abs & $\mathrm{Abs}$ \\
\hline convulsion & Abs & Abs & Abs & Abs & Abs & Abs & Abs & Abs & Abs & Abs & Abs & Abs & Abs & Abs & Abs & Abs & Abs & Abs \\
\hline salivation & Abs & Abs & Abs & Abs & Abs & Abs & Abs & Abs & Abs & Abs & Abs & Abs & Abs & Abs & Abs & Abs & Abs & Abs \\
\hline aggressiveness & Vsb & $\mathrm{Vsb}$ & Vsb & Vsb & Vsb & Abs & Abs & Abs & Abs & Abs & Abs & Abs & Abs & Abs & Abs & Abs & Abs & Abs \\
\hline Vigilance & $\mathrm{N}$ & $\mathrm{N}$ & $\mathrm{N}$ & $\mathrm{N}$ & $\mathrm{N}$ & $\mathrm{N}$ & $\mathrm{N}$ & $\mathrm{N}$ & $\mathrm{N}$ & $\mathrm{N}$ & $\mathrm{N}$ & $\mathrm{N}$ & $\mathrm{N}$ & $\mathrm{N}$ & $\mathrm{N}$ & $\mathrm{N}$ & $\mathrm{N}$ & $\mathrm{N}$ \\
\hline $\begin{array}{l}\text { Weird } \\
\text { behavior }\end{array}$ & Abs & Abs & Abs & Abs & Abs & Abs & Abs & Abs & Abs & $\mathrm{Abs}$ & Abs & Abs & Abs & Abs & Abs & Abs & Abs & Abs \\
\hline Drowsiness & Abs & Abs & Abs & Abs & Abs & Abs & Abs & Abs & Abs & Abs & Abs & Abs & Abs & Abs & Abs & Abs & Abs & Abs \\
\hline $\begin{array}{l}\text { Sound } \\
\text { sensitivity }\end{array}$ & $\mathrm{N}$ & $\mathrm{N}$ & $\mathrm{N}$ & $\mathrm{N}$ & $\mathrm{N}$ & $\mathrm{N}$ & $\mathrm{N}$ & $\mathrm{N}$ & $\mathrm{N}$ & $\mathrm{N}$ & $\mathrm{N}$ & $\mathrm{N}$ & $\mathrm{N}$ & $\mathrm{N}$ & $\mathrm{N}$ & $\mathrm{N}$ & $\mathrm{N}$ & $\mathrm{N}$ \\
\hline $\begin{array}{l}\text { Stool } \\
\text { appearance }\end{array}$ & $\mathrm{N}$ & $\mathrm{N}$ & $\mathrm{N}$ & $\mathrm{N}$ & $\mathrm{N}$ & $\mathrm{N}$ & $\mathrm{N}$ & $\mathrm{N}$ & $\mathrm{N}$ & $\mathrm{N}$ & $\mathrm{N}$ & $\mathrm{N}$ & $\mathrm{N}$ & $\mathrm{N}$ & $\mathrm{N}$ & $\mathrm{N}$ & $\mathrm{N}$ & $\mathrm{N}$ \\
\hline death & 0 & 0 & 0 & 0 & 0 & 0 & 0 & 0 & 0 & 0 & 0 & 0 & 0 & 0 & 0 & 0 & 0 & 0 \\
\hline
\end{tabular}

Variations in the average body mass of batches of rats during the experiment

The animals' body weights increased during the acute toxicity study regardless of the batch chosen. Body weight in the control batch had a $19 \mathrm{~g}$ increase, from $94 \mathrm{~g}$ on DO to $113 \mathrm{~g}$ on D14. In batch 2, an increase of $33 \mathrm{~g}$ was noted, from $135 \mathrm{~g}$ on DO to $168 \mathrm{~g}$ on D14. That of batch 3 went from $137 \mathrm{~g}$ on DO to
$168.33 \mathrm{~g}$ on D14, a $31.33 \mathrm{~g}$ increase. That of batch 4 went from $128.33 \mathrm{~g}$ on DO to $151.7 \mathrm{~g}$ on $\mathrm{D} 14$, an increase of $23.37 \mathrm{~g}$, while in batch 5 , body weight went from $122.33 \mathrm{~g}$ on DO to $151 \mathrm{~g}$ on D14, an increase of $28.67 \mathrm{~g}$. The comparison of the body masses of the same batch on DO and on D14 revealed significant differences regardless of the batch chosen (Figure-1). 


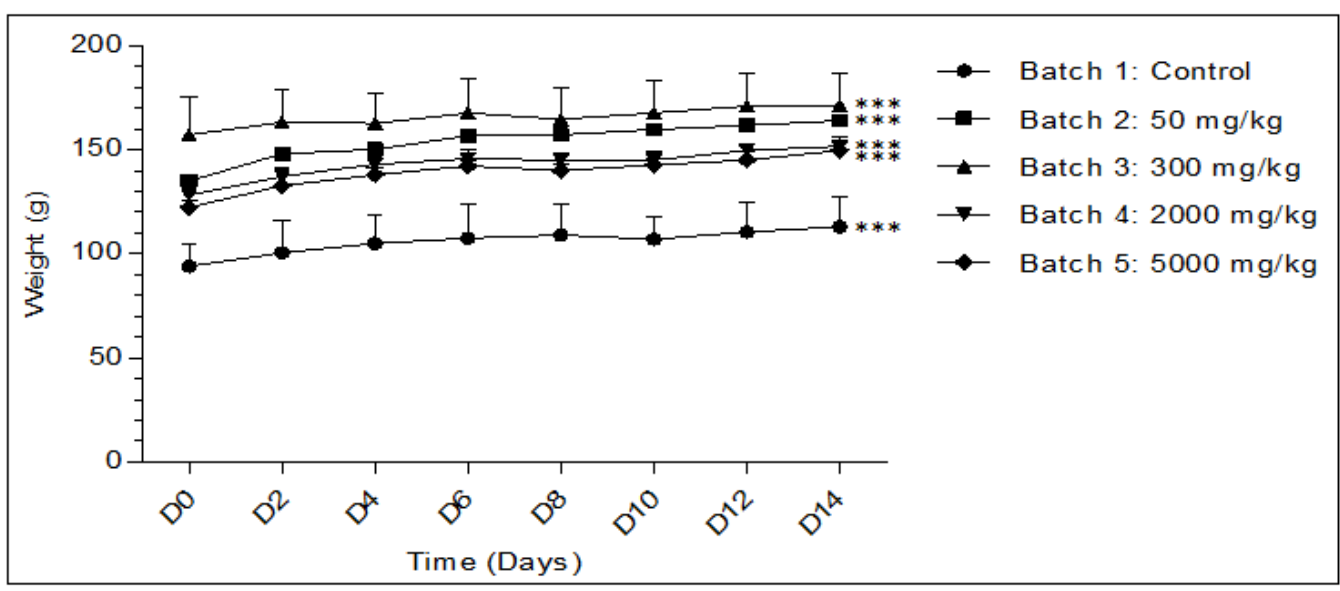

Fig-1: Changes in body mass in rat batches $* * *=$ very significant differences

\section{Masses of internal organs}

After the 14 days of observation of the rats following the acute toxicity study, the masses of the internal organs of the rats were measured. The highest heart mass $(0.57 \mathrm{~g})$ was obtained in batch 3 while the lowest $(0.46 \mathrm{~g})$ was obtained in batch 5 . The highest liver mass $(5.55 \mathrm{~g})$ was obtained in batch 1 while the lowest $(5.1 \mathrm{~g})$ was obtained in batch 3 . The highest kidney mass $(1.14 \mathrm{~g})$ was obtained in batch 1 while the lowest $(0.97 \mathrm{~g})$ was obtained in batch 2 . The highest lung mass (1.32 g) was obtained in batch 1 while the lowest $(1.16 \mathrm{~g})$ was obtained in batch 4 . Compared to the mass of the heart of the control batch, the masses of the hearts of rats of batches 2,3 , and 4 were found not to be significantly different whereas that of batch 5 was significantly different $(\mathrm{p}<0.01)$. Also, the masses of the livers and kidneys of rats in batches 2, 3 and 4 were found to be significantly different $(\mathrm{p}<0.001)$ from that of the control batch (Figure-2).

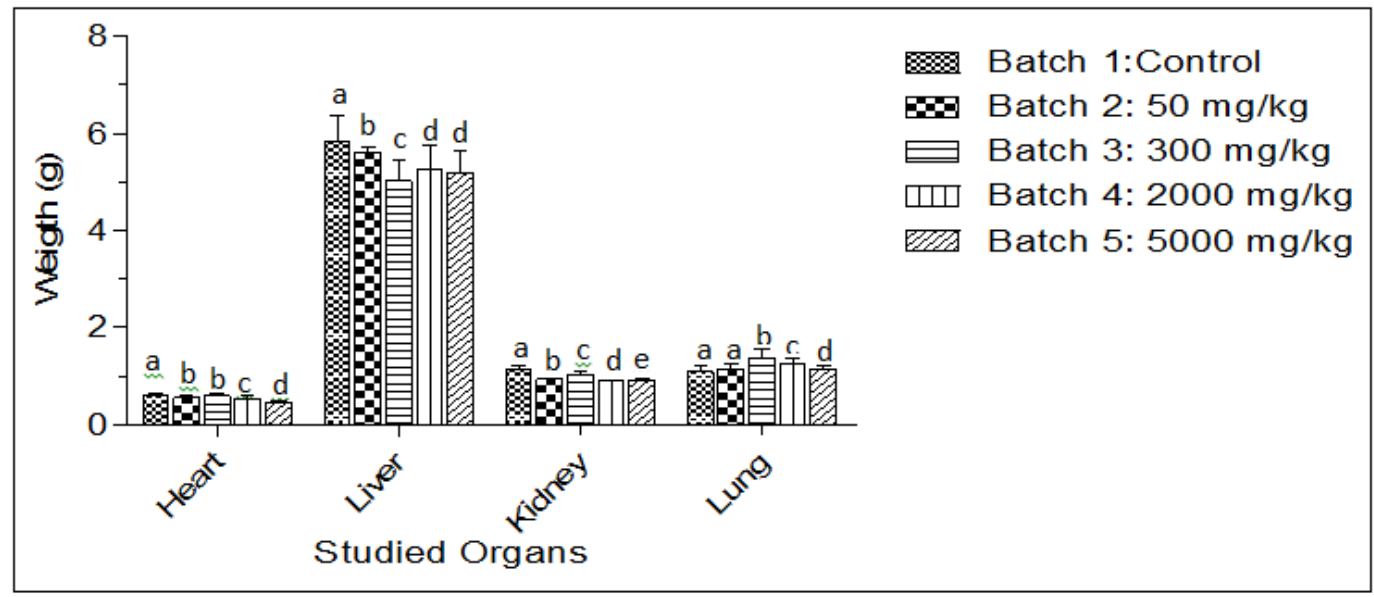

Fig-2: Masses of internal organs in batches of rats

The letters: $a, b, c, d$, e translate the covariance tests. The different letters between two lots mean that there is a significant difference between them while the same letter between two lots means that there is no significant between them

\section{Subacute toxicity of the combination of extracts}

The combination of extracts of $P$. nitida and M. cecropioides in the proportions $50: 50 \%$ was administered to the rats and the observation was made during the first $4 \mathrm{H}$ after administration, and then for 28 days. In batch 1 , the parameters observed showed no abnormality during the four weeks of observation apart from the aggressiveness of the rats. In batch 2 , the aggressiveness of rats was also noted during the first week of observation, followed by a decrease in the reaction to sound during the third week (rat 1, rat 4), then excessive motility (rat 4), tremors (rat 4, rat 5) and drowsiness (rat 4, rat 5, rat 6) during the fourth week. In batch 3, no abnormalities were noticed on the parameters observed during the first and second week apart from the aggressiveness of the rats during the first week. During the third and fourth week, nasal secretions and excretions, as well as sneezing (rat 1, rat 2 , rat 3) were noted (Table-5). 
Tankeu Séverin Elisée et al; Saudi J Med Pharm Sci, April., 2020; 6(4): 334-348

Table-5: Subacute toxicity of the combination of extracts

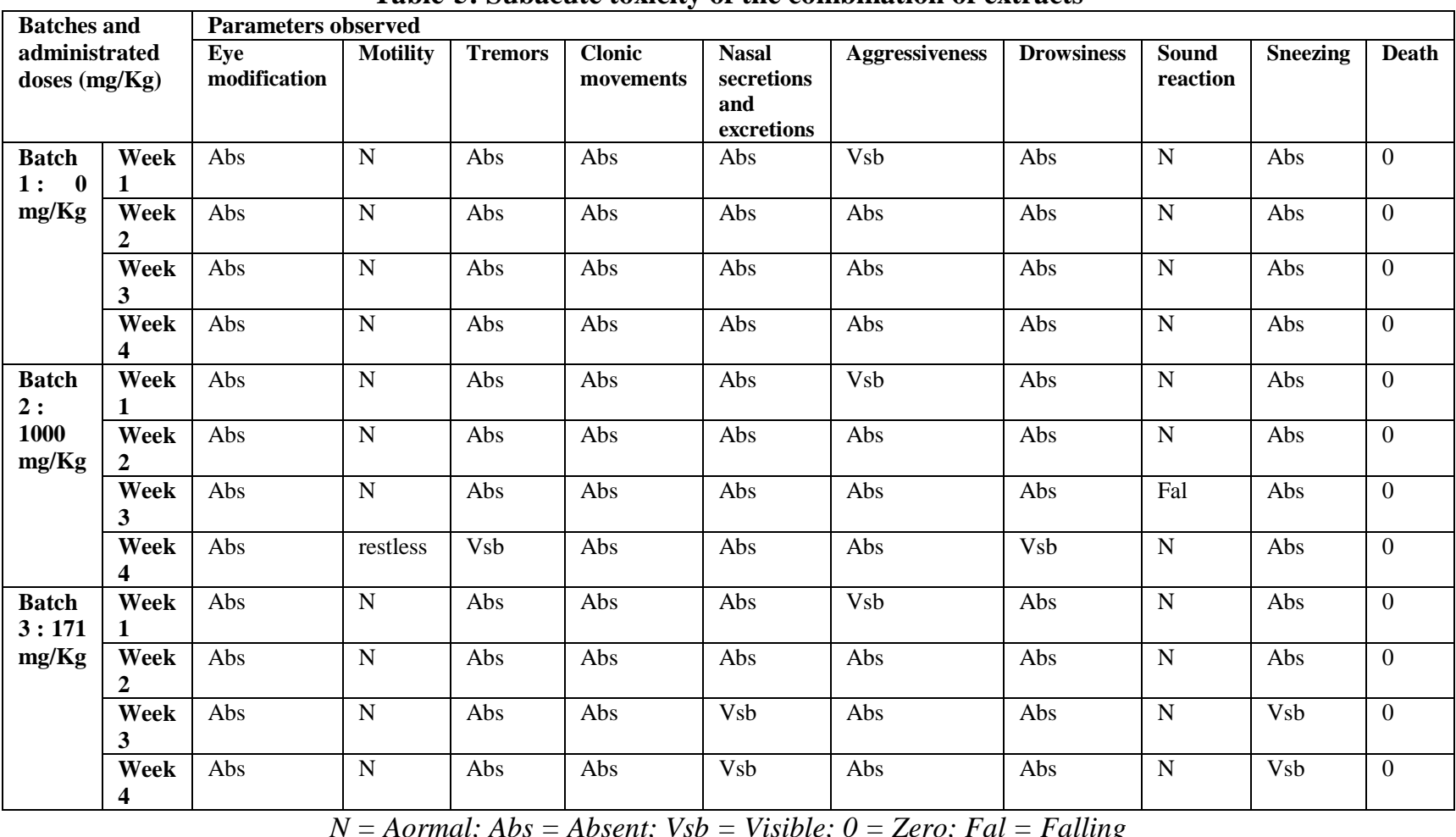

Changes in average body mass in batches of rats during the experiment

The average body weights of rats in all batches increased during the observation period. The average mass of batch 1 increased from $209.33 \mathrm{~g}$ on DO to $250.5 \mathrm{~g}$ on $\mathrm{D} 28$, an increase of $41.17 \mathrm{~g}$. The average mass of batch 2 increased from $208.17 \mathrm{~g}$ on DO to
$242.83 \mathrm{~g}$ on D28, an increase of $34.66 \mathrm{~g}$. The average mass of batch 3 increased from $247 \mathrm{~g}$ on DO to 260.33 $\mathrm{g}$ on D28, an increase of $13.33 \mathrm{~g}$. The comparison of DO versus D28 values revealed significant differences $(\mathrm{p}<0.001)$ in batches 1 and 2, while batch 3 showed values with no significant differences $(\mathrm{p}<0.05)$ (Figure-3).

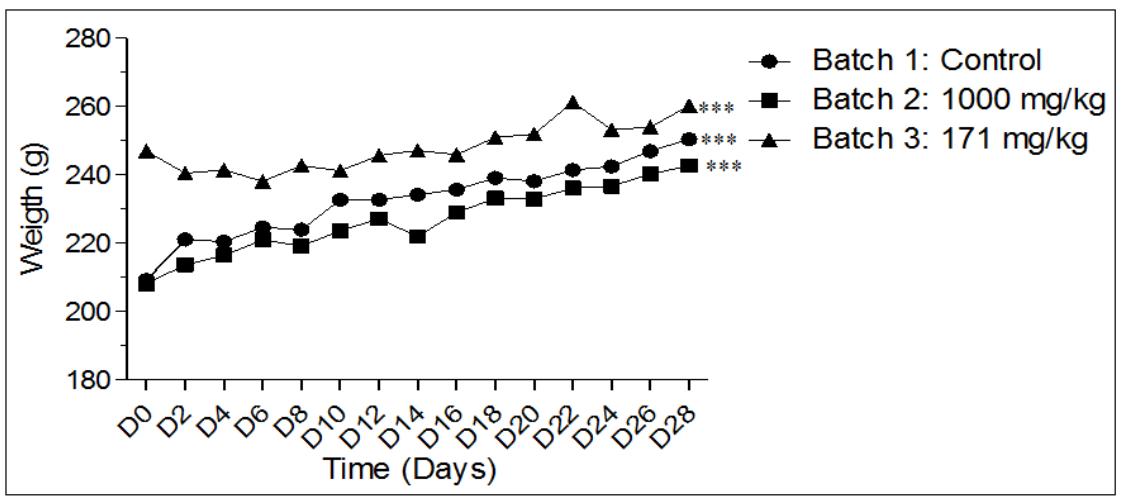

Fig-3: Variations of rats' body masses with time $* * *=$ very significant differences

\section{Variations in the average mass of batches of rats by} sex

The body masses of the animals experienced many fluctuations during the experimental period. The weight gain of females in batch 1 is greater than that of males. The differences in mean masses of females and males between the initial day and the final day are 44.6 $\mathrm{g}$ and $37.7 \mathrm{~g}$, respectively. The observation is the same in batch 2 . The differences in the average masses of males and females between the initial day and the final day are respectively $36 \mathrm{~g}$ and $33.3 \mathrm{~g}$. In batch 3 , the weight gain of males is higher than that of females. The differences in the average masses of males and females are $14 \mathrm{~g}$ and $12.7 \mathrm{~g}$ respectively between the initial day and the final day. The comparison of the values of mass gains between males and females of the same batch reveals significant differences $(p<0.001)$ for batch 1 , marginally significant $(\mathrm{p}<0.05)$ for batch 2 and not significant ( $p>0.05)$ for batch 3 (Table-6) 
Tankeu Séverin Elisée et al; Saudi J Med Pharm Sci, April., 2020; 6(4): 334-348

Table-6: Variations in the average body mass in gram of batches of rats by sex

\begin{tabular}{|c|c|c|c|c|c|c|c|c|c|c|c|c|c|c|c|c|}
\hline \multicolumn{2}{|l|}{$\mathbf{N}^{\circ}$ Batch } & D0 & D2 & D4 & D6 & D8 & D10 & D12 & D14 & D16 & D18 & D20 & D22 & D24 & D26 & D28 \\
\hline \multirow[t]{2}{*}{ Batch 1} & $F$ & $\begin{array}{l}\vec{\infty} \\
\infty \\
\ddot{d} \\
1+ \\
1+ \\
\dot{0} \\
\dot{0}\end{array}$ & 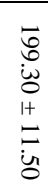 & $\begin{array}{l}\text { No } \\
\text { It } \\
\stackrel{0}{0} \\
\infty\end{array}$ & $\begin{array}{l}\tilde{O} \\
\text { I+ } \\
\text { it } \\
\text { N }\end{array}$ & $\begin{array}{l}\tilde{N} \\
\stackrel{+}{+} \\
1+ \\
\tilde{N} \\
\dot{O}\end{array}$ & 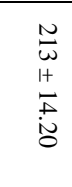 & 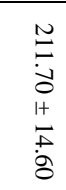 & $\begin{array}{l}\stackrel{N}{u} \\
\dot{\omega} \\
\dot{0} \\
1+ \\
\sigma \\
\sigma\end{array}$ & $\begin{array}{l}\frac{N}{\Delta} \\
\dot{\omega} \\
\text { It } \\
\vec{u} \\
\ddot{g}\end{array}$ & $\begin{array}{l}\frac{N}{N} \\
\frac{1+}{\sigma} \\
\frac{1}{\sigma}\end{array}$ & $\begin{array}{l}\stackrel{N}{v} \\
\stackrel{H}{\omega}\end{array}$ & $\begin{array}{l}\text { N } \\
\stackrel{N}{ } \\
\stackrel{+}{\sigma} \\
\forall\end{array}$ & $\begin{array}{l}\stackrel{N}{N} \\
\stackrel{N}{\sim} \\
\text { I } \\
\text { It } \\
\mathbb{N}\end{array}$ & 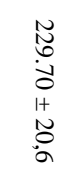 & 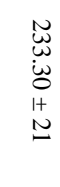 \\
\hline & $\mathrm{M}$ & $\begin{array}{l}\tilde{\omega} \\
\dot{0} \\
1+ \\
\dot{\omega} \\
\dot{\sigma}\end{array}$ & 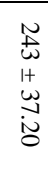 & $\begin{array}{l}\tilde{N} \\
\text { 足 } \\
1+ \\
\omega \\
\stackrel{+}{ \pm} \\
0\end{array}$ & $\begin{array}{l}\tilde{t} \\
\dot{\omega} \\
\dot{\omega} \\
+ \\
1+ \\
\omega \\
\sigma\end{array}$ & $\begin{array}{l}\tilde{N} \\
\stackrel{+}{+} \\
1+ \\
\omega \\
\stackrel{\tilde{\sigma}}{0}\end{array}$ & 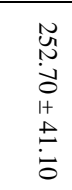 & $\begin{array}{l}\tilde{N} \\
\stackrel{+}{+} \\
1+ \\
\pm \\
\dot{\omega}\end{array}$ & $\begin{array}{l}\tilde{N} \\
\vec{\omega} \\
\dot{O} \\
H \\
+ \\
+\end{array}$ & 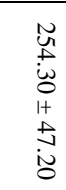 & $\begin{array}{l}\tilde{U} \\
\tilde{U} \\
\dot{\omega} \\
\stackrel{+}{+} \\
\tilde{N}\end{array}$ & 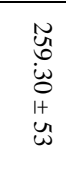 & $\begin{array}{l}\text { à } \\
\text { o } \\
\text { It } \\
\text { un }\end{array}$ & 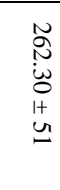 & 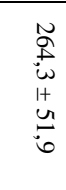 & $\begin{array}{l}\tilde{\Delta} \\
\stackrel{\Delta}{0} \\
1+ \\
\breve{\omega} \\
\dot{\omega}\end{array}$ \\
\hline \multirow[t]{2}{*}{ Batch 2} & $\mathrm{~F}$ & $\begin{array}{l}\vec{a} \\
\ddot{d} \\
\text { I+ } \\
\tilde{N} \\
\infty \\
\dot{\sigma}\end{array}$ & $\begin{array}{l}\vec{u} \\
u \\
\dot{0} \\
1+ \\
\tilde{N} \\
\stackrel{\infty}{0} \\
\ddot{0}\end{array}$ & 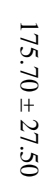 & $\begin{array}{l}\vec{\infty} \\
\stackrel{0}{0} \\
0 \\
1+ \\
w \\
w\end{array}$ & $\begin{array}{l}\overrightarrow{0} \\
\dot{\sigma} \\
1+ \\
1+ \\
\sim\end{array}$ & 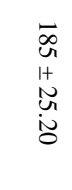 & 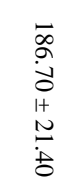 & $\begin{array}{l}\vec{\infty} \\
0 \\
1+ \\
\stackrel{N}{\sim} \\
\stackrel{0}{0}\end{array}$ & $\begin{array}{l}\vec{b} \\
\text { I } \\
\text { It } \\
\text { N }\end{array}$ & $\begin{array}{l}\vec{\nabla} \\
+ \\
\dot{\omega} \\
\text { It } \\
\mathbb{N}\end{array}$ & $\begin{array}{l}\overrightarrow{0} \\
. \\
0 \\
0 \\
+ \\
\sigma\end{array}$ & $\begin{array}{l}\vec{D} \\
\infty \\
I+ \\
\mathbb{W}\end{array}$ & 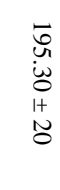 & 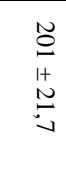 & 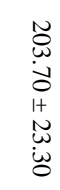 \\
\hline & $\mathrm{M}$ & 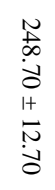 & 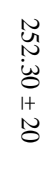 & $\begin{array}{l}\tilde{U} \\
\dot{U} \\
0 \\
+ \\
+ \\
\infty\end{array}$ & $\begin{array}{l}\tilde{\sigma} \\
\stackrel{\tilde{\omega}}{0} \\
1+ \\
\tilde{o}\end{array}$ & $\begin{array}{l}\tilde{U} \\
\dot{b} \\
1+ \\
\sigma \\
\dot{d}\end{array}$ & 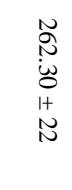 & 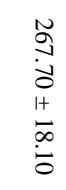 & $\begin{array}{l}\tilde{U} \\
\tilde{u} \\
+ \\
\bar{\omega} \\
\ddot{o}\end{array}$ & 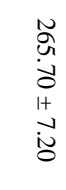 & $\begin{array}{l}\text { N } \\
\text { N } \\
\text { It } \\
=\end{array}$ & $\begin{array}{l}\text { N } \\
\text { N } \\
\text { O } \\
\text { It } \\
\text { b }\end{array}$ & $\begin{array}{l}\text { N } \\
+ \\
\dot{W} \\
0 \\
1+ \\
\infty\end{array}$ & 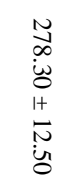 & 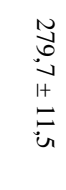 & 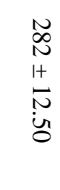 \\
\hline \multirow[t]{2}{*}{ Batch 3} & $\mathrm{~F}$ & 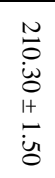 & 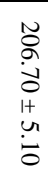 & 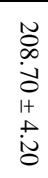 & 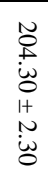 & 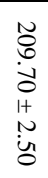 & 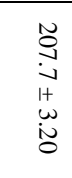 & $\begin{array}{l}N \\
\stackrel{N}{N} \\
i+ \\
\omega \\
\dot{\omega}\end{array}$ & 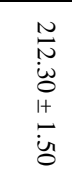 & $\begin{array}{l}\tilde{O} \\
\dot{0} \\
\dot{0} \\
1+ \\
+ \\
\dot{8}\end{array}$ & 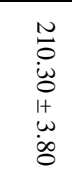 & 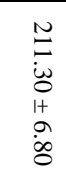 & $\begin{array}{l}\text { N } \\
\text { N } \\
+ \\
\omega \\
\dot{O}\end{array}$ & $\begin{array}{l}\stackrel{N}{=} \\
\text { I+ } \\
\stackrel{\sigma}{0}\end{array}$ & $\begin{array}{l}\stackrel{N}{a} \\
\stackrel{\omega}{\omega} \\
+ \\
+ \\
\stackrel{+}{N}\end{array}$ & $\begin{array}{l}\underset{N}{N} \\
\text { I } \\
\text { I } \\
\text { u }\end{array}$ \\
\hline & $\mathrm{M}$ & 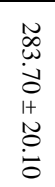 & 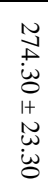 & 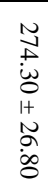 & $\begin{array}{l}N \\
N \\
N \\
1+ \\
0 \\
\mathbf{N}\end{array}$ & $\begin{array}{l}N \\
a \\
1+ \\
N \\
\tilde{+} \\
\dot{g}\end{array}$ & $\begin{array}{l}\text { N } \\
\text { H } \\
\text { It } \\
\tilde{u} \\
\ddot{b}\end{array}$ & $\begin{array}{l}\text { N } \\
\stackrel{0}{ } \\
\dot{O} \\
\text { It } \\
\text { N }\end{array}$ & $\begin{array}{l}\text { N } \\
\text { N } \\
\text { It } \\
\text { N } \\
\ddot{y}\end{array}$ & $\begin{array}{l}N \\
\infty \\
\stackrel{\infty}{\sim} \\
\\
1+ \\
N\end{array}$ & 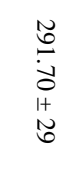 & 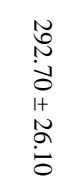 & 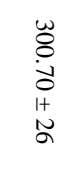 & 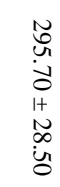 & 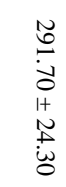 & 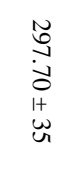 \\
\hline
\end{tabular}

\section{Average masses of the internal organs of the batches of rats during the experiment}

The weighing of the masses of the internal organs showed that the average mass of the hearts of the rats of batch $3(0.80 \mathrm{~g})$ was the highest followed by that of the rats of the control batch $(0.76 \mathrm{~g})$ and that of the rats from batch $2(0.71 \mathrm{~g})$. The comparison of the average masses of the hearts of rats from the three batches showed very significant differences $(\mathrm{p}<0.001$ and $\mathrm{p}<0.01)$ between them. The average mass of the livers of the rats in the control batch $(5.48 \mathrm{~g})$ was the highest of the average liver masses, followed by that of the rats in batch $2(5.22 \mathrm{~g})$ and then that of the rats in batch $3(5.17 \mathrm{~g})$. The comparison of the average masses of the livers of rats from the three batches showed very significant differences $(\mathrm{p}<0.001)$ between them. The mean kidney mass of batch 1 rats $(1.22 \mathrm{~g})$ was highest, followed by that of batch 3 rats $(1.145 \mathrm{~g})$ and batch 2 rats $(1.125 \mathrm{~g})$. The comparison of the average masses of the kidneys of the rats of the three batches showed significant differences $(\mathrm{p}<0.001)$ between batch 1 and batches 2 and 3 while the difference was not significant $(\mathrm{p}>0.05)$ between batch 2 and 3. Speaking of the lungs, the average mass of the rats in batch $2(2.07 \mathrm{~g})$ is the highest, followed by that of rats in the control batch $(2.03 \mathrm{~g})$ and then that batch 3 rats $(2 \mathrm{~g})$. The comparison of the average masses of the lungs of the rats of the three batches showed significant differences ( $p<0.001, p<0.01, p<0.05)$ between them. The mean mass of the pancreas of batch 3 rats $(0.7 \mathrm{~g})$ is the highest of the masses of the pancreas, followed by that of rats of the control batch $(0.64 \mathrm{~g})$ and then that of rats of batch $2(0.5 \mathrm{~g})$. The comparison of the average masses of the lungs of the rats of the three batches showed significant differences $(\mathrm{p}<0.001)$ between them (Figure-4). 


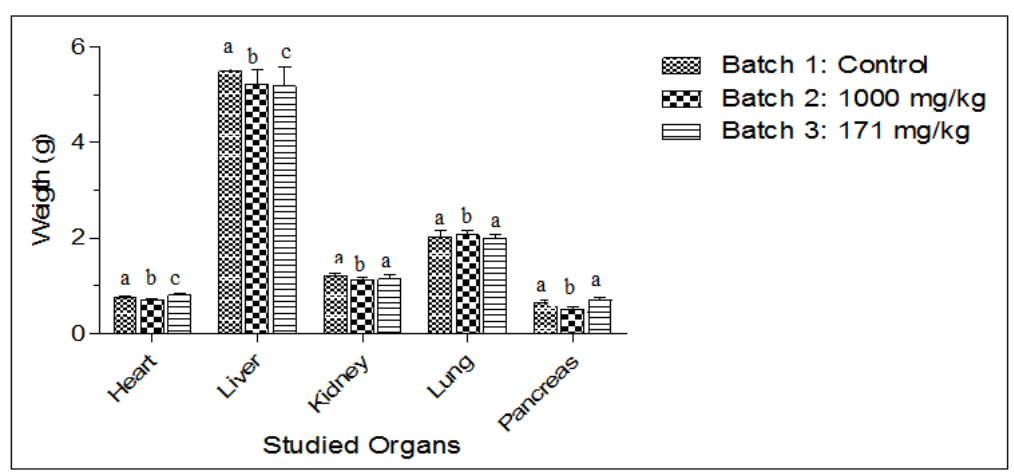

Fig-4: Average masses of the internal organs of rat groups

The letters: $a, b, c$ translate the covariance tests. The different letters between two lots mean that there is a significant difference between them while the same letter between two lots means that there is no significant between them

\section{Biochemical parameters of rats}

Analysis of the biochemical parameters of the rats' blood after studying the subacute toxicity showed that the creatinine level in the control group was lower than that in groups 2 and 3 with significant differences. The average level of urea in the control group was higher than that in group 2 with a significant difference and lower than that in group 3 with a non-significant difference. The total cholesterol, HDL cholesterol, GOT, GPT and blood sugar levels in the control group were higher than in groups 2 and 3 with significant differences. The triglyceride level of the control group was lower than that of groups 2 and 3 with a significant difference (Table-7).

Table-7: Calculated means for biochemical parameters in all batches of rats

\begin{tabular}{|c|c|c|c|c|c|c|c|c|}
\hline \multirow[t]{2}{*}{ Batch n $^{\circ}$} & \multirow[t]{2}{*}{ Creat (dg/L) } & \multirow[t]{2}{*}{ Urea $(g / L)$} & \multirow[t]{2}{*}{ Total CH (g/L) } & \multirow[t]{2}{*}{ TG $(\mathrm{g} / \mathrm{L})$} & \multirow[t]{2}{*}{ HDL (g/L) } & \multicolumn{2}{|l|}{ Trans (cUI/L) } & \multirow[t]{2}{*}{ Glycemia (g/L) } \\
\hline & & & & & & GOT & GPT & \\
\hline Batch 1 : control & $1.72 \pm 0,73^{\mathrm{a}}$ & $0.87 \pm 0.05^{\mathrm{a}}$ & $0.91 \pm 0.16^{\mathrm{a}}$ & $0.81 \pm 0.34^{\mathrm{a}}$ & $0.38 \pm 0.07^{\mathrm{a}}$ & $298.10 \pm 20.17^{\mathrm{a}}$ & $72.50 \pm 7.20^{\mathrm{a}}$ & $0,96 \pm 0.030^{\mathrm{a}}$ \\
\hline Batch 2 & $2.12 \pm 0.34^{b}$ & $0.61 \pm 0.02^{b}$ & $0.77 \pm 0.18^{b}$ & $0.93 \pm 0.12^{b}$ & $0.26 \pm 0.11^{\mathrm{b}}$ & $122.10 \pm 12.15^{b}$ & $66.80 \pm 8.24^{b}$ & $0.82 \pm 0.06^{b}$ \\
\hline Batch 3 & $2.01 \pm 0.82^{\mathrm{c}}$ & $0.91 \pm 0.06^{\mathrm{a}}$ & $0.86 \pm 0.15^{\mathrm{c}}$ & $0.93 \pm 0.15^{b}$ & $0.28 \pm 0.04^{\mathrm{c}}$ & $139.10 \pm 9.21^{\mathrm{c}}$ & $28.18 \pm 3.21^{\mathrm{c}}$ & $0.69 \pm 0.02^{c}$ \\
\hline
\end{tabular}

Values are presented as mean \pm standard deviation. Creat $=$ Creatinine $; C H=$ Cholesterol; $T G=$ Triglycerides; HDL $=$ High-Density Lipoproteins; Trans = Transaminases; GOT = Glutamate Oxolo-acetate Transaminase; GPT = Glutamate Pyruvate Transaminase The letters: $a, b$, $c$ translate the covariance tests. The different letters between two lots mean that there is a significant difference between them while the same letter between two lots means that there is no significant difference between them

\section{Biochemical parameters of batches of rats by sex}

The creatinine level was higher in males than in females in batch 1 with a significant difference $(\mathrm{p}<$ 0.001 ) while in batches 2 and 3 it was higher in females with significant differences $(\mathrm{p}<0.001)$. The urea rate was higher in males than in females in batches 1, 2 and 3 with significant differences in all batches. Cholesterol levels were higher in males than in females in batch 3 , but showed no significant differences in batches 1 and 2. Triglyceride levels were higher in females in batches 1 and 3 than in males, with significant differences $(\mathrm{p}<$ $0.001, \mathrm{p}<0.05)$ in batches 1 and 3 but showed no significant difference $(p>0.05)$ in batch 2 . HDL cholesterol was higher in females in batch 1 than in males whereas in batches 2 and 3, it was higher in males. The differences were significant in all batches. The GOT level was higher in females in batch 1 than in males, while in batches 2 and 3 it was higher in males. The differences were significant $(\mathrm{p}<0.01)$ for batch 1 and not significant for batches 2 and 3. The GPT level was higher in females in batches 1,2 and 3 than in males with significant differences $(p<0.001)$. The blood sugar level in females of batches 1,2 and 3 showed no significant difference $(\mathrm{p}<0.05)$ compared to that in males (Table-8).

Table-8: Calculated means for biochemical parameters in all batches of rats by sex

\begin{tabular}{|c|c|c|c|c|c|c|c|c|c|}
\hline \multicolumn{2}{|l|}{ Batch n $^{\circ}$} & \multirow[t]{2}{*}{ Creat $(\mathrm{dg} / \mathrm{L})$} & \multirow[t]{2}{*}{ Urea $(g / L)$} & \multirow[t]{2}{*}{ Total CH (g/L) } & \multirow[t]{2}{*}{ TG $(g / L)$} & \multirow[t]{2}{*}{ HDL (g/L) } & \multicolumn{2}{|l|}{ Trans (cUI/L) } & \multirow[t]{2}{*}{ Glycemia $(\mathrm{g} / \mathrm{L})$} \\
\hline & & & & & & & GOT & GPT & \\
\hline \multirow{2}{*}{$\begin{array}{l}\text { Batch } \\
\text { control }\end{array}$} & $\mathbf{F}$ & $1.63 \pm 0.06^{\mathrm{a}}$ & $0.84 \pm 0.09^{\mathrm{a}}$ & $0.93 \pm 0.02^{\mathrm{a}}$ & $0.92 \pm 0.23^{\mathrm{a}}$ & $0.43 \pm 0.08^{\mathrm{a}}$ & $303.47 \pm 72.03^{\mathrm{a}}$ & $87.30 \pm 0.14^{\mathrm{a}}$ & $1 \pm 0.02^{\mathrm{a}}$ \\
\hline & M & $1.80 \pm 0.09^{\mathrm{b}}$ & $0.9 \pm 0.08^{\mathrm{b}}$ & $0.89 \pm 0.10^{\mathrm{a}}$ & $0.68 \pm 0.32^{\mathrm{b}}$ & $0.33 \pm 0.05^{\mathrm{b}}$ & $292.67 \pm 11.16^{b}$ & $57.7 \pm 11.21^{\mathrm{b}}$ & $0.91 \pm 0.04^{\mathrm{b}}$ \\
\hline \multirow[t]{2}{*}{ Batch 2} & $\mathbf{F}$ & $2.30 \pm 0.09^{\mathrm{a}}$ & $0.55 \pm 0.02^{\mathrm{a}}$ & $0.76 \pm 0.04^{\mathrm{a}}$ & $0.91 \pm 0.20^{\mathrm{a}}$ & $0.24 \pm 0.06^{\mathrm{a}}$ & $118 \pm 16.20^{\mathrm{a}}$ & $77.50 \pm 21.02^{\mathrm{a}}$ & $0.85 \pm 0.03^{\mathrm{a}}$ \\
\hline & $\mathbf{M}$ & $1.93 \pm 0.07^{\mathrm{b}}$ & $0.67 \pm 0.08^{\mathrm{b}}$ & $0.78 \pm 0.30^{\mathrm{a}}$ & $0.95 \pm 0.10^{\mathrm{a}}$ & $0.28 \pm 0.10^{\mathrm{b}}$ & $126.19 \pm 17.23^{\mathrm{a}}$ & $56.10 \pm 9.52^{\mathrm{b}}$ & $0.79 \pm 0.20^{\mathrm{b}}$ \\
\hline \multirow[t]{2}{*}{ Batch 3} & $\mathbf{F}$ & $2.08 \pm 0.04^{\mathrm{a}}$ & $0.84 \pm 0.06^{\mathrm{a}}$ & $0.78 \pm 0.50^{\mathrm{a}}$ & $0.96 \pm 0.30^{\mathrm{a}}$ & $0.27 \pm 0.04^{\mathrm{a}}$ & $132.13 \pm 24.06^{\mathrm{a}}$ & $34 \pm 60.54^{\mathrm{a}}$ & $0.72 \pm 0.01^{\mathrm{a}}$ \\
\hline & M & $1.94 \pm 0.08^{\mathrm{b}}$ & $0.98 \pm 0.03^{\mathrm{b}}$ & $0.96 \pm 0.10^{b}$ & $0.90 \pm 0.31^{\mathrm{b}}$ & $0.29 \pm 0.06^{\mathrm{b}}$ & $146 \pm 14.35^{\mathrm{a}}$ & $22.36 \pm 3.10^{\mathrm{b}}$ & $0.66 \pm 0.04^{\mathrm{b}}$ \\
\hline
\end{tabular}

Values are presented as mean \pm standard deviation. Creat $=$ Creatinine; $C H=$ Cholesterol; $T G=$ Triglycerides; $H D L=H i g h-D e n s i t y$ Lipoproteins; Trans = Transaminases; GOT = Glutamate Oxolo-acetate Transaminase $;$ GPT = Glutamate Pyruvate Transaminase . The letters: $a$, $b$ translate the covariance tests. The different letters between two lots mean that there is a significant difference between them while the same letter between two lots means that there is no significant difference between them 


\section{Hematological parameters of rats}

After studying the subacute toxicity, the hematological parameters of the rats were determined. The values of these parameters except for neutrophils all showed a significant difference $(\mathrm{p}<0.01)$, with the highest values observed in batch 3 , then the control batch and finally, batch 2 with the lowest values (Table9).

Table-9: Hematological parameters of rats

\begin{tabular}{|l|l|l|l|l|l|l|l|}
\hline Batch n $^{\circ}$ & WBC $(\mathbf{U} / \boldsymbol{\mu L})$ & RBC $(\mathbf{g} / \mathbf{L})$ & $\mathbf{H c t}(\mathbf{g} / \mathbf{L})$ & $\mathbf{M C V}\left(\mathbf{U} / \boldsymbol{\mu m}^{\mathbf{3}}\right)$ & $\mathbf{M C H C}(\mathbf{c g} / \mathbf{L})$ & $\mathbf{P L T}\left(\mathbf{U} / \boldsymbol{\mu m}^{\mathbf{3}}\right)$ & $\mathbf{N}^{\mathbf{3}}\left(\mathbf{U} / \boldsymbol{\mu m}^{\mathbf{3}}\right)$ \\
\hline Batch 1: Control & $7.86 \pm 1.71^{\mathrm{a}}$ & $16.07 \pm 1.80^{\mathrm{a}}$ & $38.40 \pm 4.20^{\mathrm{a}}$ & $64.80 \pm 2.10^{\mathrm{a}}$ & $41,50 \pm 3.20^{\mathrm{a}}$ & $344.63 \pm 23.50^{\mathrm{a}}$ & $8 \pm 2.43^{\mathrm{a}}$ \\
\hline Batch 2 & $7.32 \pm 1.9^{\mathrm{b}}$ & $14.2 \pm 1.07^{\mathrm{b}}$ & $36.40 \pm 6.20^{\mathrm{b}}$ & $59.50 \pm 1.30^{\mathrm{b}}$ & $36.70 \pm 2.40^{\mathrm{b}}$ & $320.23 \pm 32.70^{\mathrm{b}}$ & $9.33 \pm 3.10^{\mathrm{b}}$ \\
\hline Batch 3 & $9.13 \pm 0.92^{\mathrm{c}}$ & $17.2 \pm 1.30^{\mathrm{c}}$ & $43.10 \pm 3.03^{\mathrm{c}}$ & $68 \pm 1.60^{\mathrm{c}}$ & $44.20 \pm 1.51^{\mathrm{c}}$ & $364.53 \pm 13.60^{\mathrm{c}}$ & $10.20 \pm 1.70^{\mathrm{c}}$ \\
\hline
\end{tabular}

Values are presented as mean \pm standard deviation. $W B C=$ White blood cells; RBC $=$ Red blood cells; Hct $=$ Hematocrit $;$ MCV $=$ Mean Corpuscular Volume; $M C H=$ Mean corpuscular hemoglobin; $M C H C=$ Mean corpuscular hemoglobin concentration; PLT = Platelet count; $N=$ Neutrophil count

\section{Hematological parameters of rats by sex}

The WBC count was higher in females than in males in all batches. The RBC level, the $\mathrm{MCH}$ was higher in males than in females of all batches. The hematocrit was higher in males than in females in batches 1 and 2 while in batch 3 it was higher in females. $\mathrm{MHCH}$ values showed significant differences, with values higher in females in batches 1 and 3 , but higher in males in batch 2 . The PLT count in the blood is higher in males than in females in batches 1 and 2 but higher in females than in males in batch 3 . The neutrophil levels were higher in males than in females in batches 1 and 3 whereas it was higher in the females in batch 2 (Table-10).

Table-10: Hematological parameters of rats by sex

\begin{tabular}{|c|c|c|c|c|c|c|c|c|}
\hline \multicolumn{2}{|l|}{ Batch n $^{\circ}$} & WBC $(\mathbf{U} / \mu \mathrm{L})$ & RBC (g/L) & Het (g/L) & $\operatorname{MCV}\left(\mathbf{U} / \mu \mathrm{m}^{3}\right)$ & MCHC (cg/L) & PLT $\left(\mathrm{U} / \mu \mathrm{m}^{3}\right)$ & $\mathbf{N}\left(\mathbf{U} / \mu \mathbf{m}^{3}\right)$ \\
\hline \multirow[t]{2}{*}{ Batch 1 : control } & $\mathbf{F}$ & $8,7 \pm 2,1^{\mathrm{a}}$ & $15,49 \pm 0,5^{\mathrm{a}}$ & $37,9 \pm 3,2^{\mathrm{a}}$ & $67,1 \pm 1,1^{\mathrm{a}}$ & $43,4 \pm 3,5^{\mathrm{a}}$ & $292,53 \pm 39,6^{\mathrm{a}}$ & $5,5 \pm 0,7^{\mathrm{a}}$ \\
\hline & $\mathbf{M}$ & $7,02 \pm 1,6^{b}$ & $16,65 \pm 1^{b}$ & $38,9 \pm 6,7^{\mathrm{a}}$ & $62,5 \pm 2,7^{b}$ & $39,6 \pm 3,1^{\mathrm{b}}$ & $396,73 \pm 22,3^{b}$ & $10,6 \pm 1,3^{b}$ \\
\hline \multirow{2}{*}{ Batch 2} & $\mathbf{F}$ & $8,04 \pm 0,9^{\mathrm{a}}$ & $13,86 \pm 0,3^{\mathrm{a}}$ & $35,77 \pm 1,6^{\mathrm{a}}$ & $58,8 \pm 1,4^{\mathrm{a}}$ & $34,9 \pm 1,4^{\mathrm{a}}$ & $292,83 \pm 27,4^{\mathrm{a}}$ & $12,73 \pm 1,23^{\mathrm{a}}$ \\
\hline & $\mathbf{M}$ & $6,6 \pm 2,01^{b}$ & $14,54 \pm 1,25^{\mathrm{a}}$ & $37,02 \pm 5,4^{\mathrm{a}}$ & $60,2 \pm 2,3^{\mathrm{a}}$ & $38,5 \pm 4,7^{b}$ & $347,63 \pm 42,9^{b}$ & $5,93 \pm 0,42^{b}$ \\
\hline \multirow[t]{2}{*}{ Batch 3} & $\mathbf{F}$ & $9,76 \pm 1,1^{\mathrm{a}}$ & $16,57 \pm 0,3^{\mathrm{a}}$ & $44,68 \pm 2,3^{\mathrm{a}}$ & $64,8 \pm 2.1^{\mathrm{a}}$ & $40,9 \pm 1,5^{\mathrm{a}}$ & $392,9 \pm 33,6^{\mathrm{a}}$ & $8,4 \pm 1,7^{\mathrm{a}}$ \\
\hline & $\mathbf{M}$ & $8,49 \pm 0,3^{b}$ & $17,82 \pm 1,2^{\mathrm{b}}$ & $41,52 \pm 4,5^{b}$ & $71,2 \pm 1,1^{\mathrm{b}}$ & $35,5 \pm 1,6^{\mathrm{b}}$ & $336,1 \pm 69,78^{b}$ & $12 \pm 1,01^{b}$ \\
\hline
\end{tabular}

Values are presented as mean \pm standard deviation. $W B C=$ White blood cells; RBC $=$ Red blood cells; Hb $=$ Hemoglobin; Hct $=$ Hematocrit; $M C V=$ Mean Corpuscular Volume $; M C H=$ Mean corpuscular hemoglobin; MCHC = Mean corpuscular hemoglobin concentration; $P L T=$ Platelet count N $=$ Neutrophil count

\section{DISCUSSION}

Phytochemical screening of the extracts from the two plants made it possible to highlight the presence of various phytochemical groups. The tests for alkaloids, sterols, terpenes, phenols, flavonoids, saponins, coumarins, reducing sugars, tannins were positive with at least one solvent, while those for anthraquinones and anthocyanins were negative with all the solvents whatever the species considered. The presence of these secondary metabolites in plant extracts is believed to be responsible for their numerous pharmacological properties. Saponins have a bitter and acrid taste. They are heterosides with a surfactant property. Alkaloids have anti-ulcer, anti-hypertensive, antiinflammatory and analgesic properties. Flavonoids have antimicrobial and antimalarial properties and are also involved in the fight against venereal diseases [20]. All ethyl acetate tests on $P$. nitida extracts were negative. These results are corroborated by other researchers [21-24].

The acute toxicity study focused on the observation of physiological changes in white albino rats of the Wistar strain. The combination of extracts of $P$. nitida and $M$. cecropioides in the proportions 50:50\% was administered to rats and the observation was made during the first $8 \mathrm{~h}$, then everyday, for 14 days. At the end of the 14 days of observation, the parameters studied showed no anomalies, except for the aggressiveness of the rats during the first day. No deaths were recorded, giving an $\mathrm{LD}_{50}$ greater than 5,000 $\mathrm{mg} / \mathrm{Kg}$. Therefore, this combination can be classified as non-toxic according to the Hodge and Stenner scale of toxicity [25]. These results are corroborated by those of other researchers [21, 22]. Etame et al. [23], Ngo Lemba Tom [24], Zerriouh [26], Sanogo et al. [27], found similar results in their work. The study of the toxicity of a substance is the set of pharmacological tests, which determine the degree or harmfulness of the substance in order to regulate its use. The toxicity can be assessed, among other things, by determining the $\mathrm{LD}_{50}$. The $\mathrm{LD}_{50}$ corresponds to the dose capable of killing under determined conditions, half of the animals tested in the same animal species. This determination is based on the evaluation of the all-or-nothing responses: death or survival of the animals. The experimental protocol consists in experimenting on 5 to 6 batches of 5 to 7 animals to which increasing doses of the test substance are administered, so as to obtain a varying percentage of mortality. This is because it is impossible to immediately obtain $50 \%$ of deaths from a single group. 
An increase in body mass was observed during this study. This is probably due to the fact that the combination of the aqueous extracts of $P$. nitida and $M$. cecropioides did not disturb the basic metabolism of the animals tested. These results support the physiological parameters observed and show that the combination of aqueous extracts of $P$. nitida and $M$. cecropioides would be very little toxic and appropriate for the formulation of improved traditional medicines after the study of pharmacological activities and determining effective doses. Etame et al [23] and Dibong et al [28] in their work found similar results, meaning that the weight gain of males and females was generally increasing regardless of the batch chosen. The action of a toxic substance can be evaluated according to parameters such as the mode of administration (oral, intravenous, intraperitoneal), the dose administered, the observed mortality rate, weight changes and the histology of certain organs. The modification of certain biochemical parameters of the blood called toxicity markers, which include alanine amino transferases and aspartate amino transferases (ASAT) can also be taken into consideration, as well as bilirubin, creatinine and urea [29]. According to Wepierre [30], toxicity disorders often manifest themselves after a long impregnation of the organism. Repeated administration toxicity tests in animals are always carried out when a molecule is of potential therapeutic benefit. Certain therapeutic risks which appear only under specific conditions are the subject of special tests, namely the evaluation of teratogenic, carcinogenic and mutagenic effects.

Liver and kidney masses of rats were higher in the control batch than in the test batches in this study. This would mean that the combination of the aqueous extracts of $P$. nitida and $M$. cecropioides would have hepatic and nephroprotective effects, as observed by other researchers $[23,28]$.

During the subacute toxicity study, no abnormality of the parameters observed was noticed during the four weeks of observation in batch 1, apart from the aggressiveness of the rats during the first week. In batch 2, the aggressiveness of the rats is noted during the first week of observation, a decrease in the reaction to sound during the third week (rat 1, rat 4) then agitation (rat 4), tremors (rat 4, rat 5) and drowsiness (rat 4, rat 5, rat 6) during the fourth week. In batch 3, no abnormalities of the parameters observed were noticed during the first and second week apart from the aggressiveness of the rats during the first week. During the third and fourth week, salivary secretions, nasal excretions and sneezing (rat 1, rat 2, rat 3) were noted. All of these behavioral changes during the study would indicate a likely onset of medium-term toxicity from the combination of the extracts from the two plants. These results are similar to those of Manda et al. [29], Ngo Lemba Tom [24].
Etame et al. [23] in their work, found contrary results, Observation of behavior throughout the study period made it possible to observe that, whatever the dose of the extract administered, no behavioral change had was observed during the 28 days. Sanogo et al., [27] recorded deaths during the study period.

The average body weights of rats in all batches increased during the observation period. The average mass of batch 1 increased from $209.33 \mathrm{~g}$ on day zero to $250.5 \mathrm{~g}$ on D28, an increase of $41.17 \mathrm{~g}$. The average mass of batch 2 increased from $208.17 \mathrm{~g}$ on DO to $242.83 \mathrm{~g}$ on day 28 , an increase of $34.66 \mathrm{~g}$. The average mass of batch 3 increased from $247 \mathrm{~g}$ on day zero to $260.33 \mathrm{~g}$ on day 28 , an increase of $13.33 \mathrm{~g}$. The comparison of the initial values of day zero with the final values of day 28 using the ANOVA test revealed significant differences $(\mathrm{p}<0.001)$ in batches 1 and 2 , and no significant differences $(\mathrm{p}<0.05)$ in batch 3 . These results do not support the hypothesis of a probable medium-term toxicity of the doses of extract administered to the batches of rats because if this were the case, a fall in the body masses of the various batches would be observed due to the fact of the disturbance of the normal metabolism of animals tested. Researchers found similar results in their work on Catharanthus roseus, Rauwolfia vomitoria, Hibiscus sabdarifa (plant and similarities with $P$. nitida and $M$. cecropioides) [29]. The weight gain of females in batch 1 is greater than that of males. The differences in mean masses of females and males between the initial day and the final day are $44.6 \mathrm{~g}$ and $37.7 \mathrm{~g}$, respectively. The observation is the same in batch 2 . The differences in the average masses of males and females between the initial day and the final day are respectively $36 \mathrm{~g}$ and $33.3 \mathrm{~g}$. In batch 3 , the weight gain of males is higher than that of females. The differences in the average masses of males and females are $14 \mathrm{~g}$ and $12.7 \mathrm{~g}$ respectively between the initial day and the final day. The comparison of the values of mass gains between males and females of the same batch reveals significant differences $(\mathrm{p}<0.001)$ for batch 1 , marginally significant $(\mathrm{p}<0.05)$ for batch 2 and no significant difference $(\mathrm{p}>0.05)$ for batch 3. Etame et al., [23] in their work found that the weight gain of males and females was generally increasing regardless of the batch chosen.

Analysis of the biochemical parameters of the rats' blood after studying the subacute toxicity showed that the creatinine level in the control group was lower than that in groups 2 and 3 with significant differences. The average level of urea in the control group was higher than that in group 2 with a significant difference and lower than that in group 3 with a non-significant difference. The total cholesterol, HDL cholesterol, GOT, GPT and blood sugar levels in the control group were higher than in groups 2 and 3 with significant differences. The triglyceride level of the control group 
was lower than that of groups 2 and 3 with significant differences. The higher creatinine level in the test batches compared to the control batch would reflect a likely perceptible toxicity at the endocrine level. The kidneys being the organs that release creatinine into the blood in the event of toxicity, the combination of the aqueous extracts of $P$. nitida and $M$. cecropioides would be nephrotoxic in the medium term. Likewise, the higher transaminase levels (GOT and GPT) in the control group than in the test groups with significant differences would show that the combination of the aqueous extracts of $P$. nitida and $M$. cecropioides would be hepatoprotective. Ngo Lemba Tom [24] found similar results in his work. The creatinine level was higher in males than in females in batch 1 with a significant difference $(\mathrm{p}<0.001)$ while in batches 2 and 3 it was higher in females with significant differences $(\mathrm{p}<0.001)$. The urea rate was higher in males than in females in batches 1,2 and 3 with significant differences in all batches. Cholesterol levels were higher in females in batch 1 than in males, while in batches 2 and 3 it was higher in males than in females with no significant differences in batches 1 and 2 and significant in batch 3 . Triglyceride levels were higher in females in batches 1 and 3 than in males, while it was higher in males in batch 2 than in females with significant differences $(p<0.001, p<0.05)$ in bacthes 1 and 3 and not significant $(\mathrm{p}>0.05)$ in batch 2 . HDL cholesterol was higher in females in batch 1 than in males, while in batches 2 and 3 it was higher in males. The differences were significant in all batches. The GOT level was higher in females in batch 1 than in males, while in bathes 2 and 3 it was higher in males. The differences were significant $(\mathrm{p}<0.01)$ for batch 1 and not significant for batches 2 and 3. The GPT level was higher in females in batches 1,2 and 3 than in males with significant differences $(\mathrm{p}<0.001)$. The blood sugar level in batches 1, 2 and 3 showed no significant differences $(\mathrm{p}<0.05)$. The urea rate was higher in males than in females in all batches. This would show that the males were more sensitive to the combination of extracts. Likewise, the GPT level was higher in females than in males. This would mean that the females were more hepatic sensitive to the combination of the extracts.

After studying the subacute toxicity, the hematological parameters of the rats were determined. The values of these parameters except for neutrophils were all higher in the control batch than in batch 2 and lower in the control batch than in batch 3 with significant differences $(p<0.01)$. The rates of several hematological parameters of the rats of batches 2 and 3 were lower than those of the rats of the control batch. This shows that repeated administration of the combination of extracts over a relatively long period has not been toxic to animals. These results support those obtained with biochemical parameters and are similar to those of Etame et al. [23]. The extracts of the two plants can be used without danger for the formulation of improved traditional medicines if the preliminary pharmacological activities are demonstrated. The WBC count was higher in females than in males in all batches. The RBC level, the average corpuscular hemoglobin content were higher in males than in females of all batches. The rate of hematocrites was higher in males than in females in batches 1 and 2 while in batch 3 it was higher in females. The average corpuscular hemoglobin concentration was higher in females than in males of batches 1 and 3 with significant differences whereas in batch 2 , it is higher in males than in females with a significant difference. The level of platelets in the blood is higher in males than in females in batches 1 and 2 but higher in females than in males in batch 3 . The level of neutrophils was higher in males than in females in batches 1 and 3, while it was higher in females in batch 2. Manda et al., [29] and Etame et al., [23], found similar results in their work.

\section{CONCLUSION}

The general objective of this work has been to study the acute and subacute toxicities of the combination of the aqueous extracts of the bark of the trunk of $M$. cecropioides and the fruits of $P$. nitida. The masses of extracts obtained after concentration of the macerate in an oven at $50{ }^{\circ} \mathrm{C}$ were $28 \mathrm{~g}$ and $9.3 \mathrm{~g}$ respectively for $P$. nitida and $M$. cecropioides with respective extraction yields of $14 \%$ and $4.65 \%$. The tests for microbial germs likely to reveal the contamination of the extracts were negative. The extracts are therefore of high quality and can be used for the rest of the study. Tests for alkaloids, sterols, terpenes, phenols, flavonoids, saponins, coumarins, reducing sugars, tannins were positive with at least one solvent, while those for Anthraquinones and anthocyanins were negative with all the solvents whatever the species considered. At the end of the 14 days of study of the acute toxicity, no abnormality of the parameters studied was noted except for the aggressiveness of the rats during the first day of observation. In addition, no deaths have been recorded. The $\mathrm{LD}_{50}$ is therefore greater than $5000 \mathrm{mg} / \mathrm{Kg}$. Many parameters observed varied during the subacute toxicity study period. The average body weights of rats in all batches increased during the observation period. The weight gain of females in batches 1 and 2 was greater than that of males, while in batch 3 , the weight gain of males was greater than that of females. Analysis of the biochemical parameters showed that many parameters were higher in the control group than in the test groups. The determination of the hematological parameters revealed that all these parameters, with the exception of neutrophils, were higher in the control batch than in batch 2 and lower in the control batch than in batch 3 with significant differences. The combination of the aqueous extracts was therefore judged to be of good quality for the formulation of the improved traditional 
medicines provided that the pharmacological activities are confirmed.

\section{ACKNOWLEDGMENTS}

We thank DAAD for the fruitful scientific cooperation between the University of the Saarlandes (Germany) and the University of Douala (Cameroon).

\section{REFERENCES}

1. Allabi, A. C., Busiac, K., Ekanmiana, V., \& Bakiono F. (2011). The use of medicinal plants in self-care in the Agonlin region of Benin. Journal of Ethnopharmacology, 133, 234-243.

2. Tahraoui, A., El-Hilaly, J., Israili, Z. H., \& Lyoussi, B. (2007). Ethnopharmacological survey of plants used in the traditional treatment of hypertension and diabetes in south-eastern Morocco (Errachidia province). Journal of Ethnopharmacology, 110:105-117.

3. Baldé, M. D., Baldé, N. M., Kaba, M. L., Diallo, I., Diallo, M. M., Kake, A., Bah, D., \& Camara A. (2006). Epidémiologie et anomalies métabolites au Foutah-Djallon en Guinée. Mali Medical, 21(3) :19-22.

4. Ouedraogo, S., Belemnaba, L., Traore, A., Lompo, M., Bucher, B., \& Guissou, I. P. (2008). Etude de la toxicité et des propriétés pharmacologiques de l'extrait aqueux d'Anogeissus leiocarpus (DC) Guill. et Perr (Combretaceae). Pharmacopée et Médecine traditionnelle Africaines, 15 :18-22.

5. Eddouks, M., Maghrani, M., Lemhadri, A., Ouahidi, M. L., \& Jouad, H. (2002). Ethnopharmacological survey of medicinal plants used for the treatment of diabetes mellitus, hypertension and cardiac diseases in the south-east region of Morocco (Tafilalet). Journal of Ethnopharmacology, 82:97-103.

6. Jouad, H., Haloui, M., Rhiouani, H., El-Hilaly, J., \& Eddouks, M. (2001). Ethnobotanical survey of medicinal plants used for the treatment of diabetes, cardiac and renal diseases in the North centre region of Morocco (Fez-Boulemane). Journal of Ethnopharmacology, 77:175-182.

7. Kouadio, F., Kanko, C., Juge, M., Grinaux, N., Jean, A., N'guessan, Y. T. \& Petit, J. Y. (2000). Analgesic and antiinflammatory activities of an extracts from Parkiabiglobosa used in traditional medicine in the Ivory Coast. Phytother Res, 14, 635-637.

8. Isérin, P., Masson, M., \& Kedellini, J. P. (Eds. Larousse/VUEF) (2001). Encyclopédie des plantes médicinales, Identifications, Préparations, Soins (335). Paris, France.

9. Guindo, I. (2005). Etude du traitement traditionnel de l'hypertension artérielle au Mali. Thèse de pharmacie FMPOS, Bamako, Mali. 126.

10. Ba, S. H. G. (2005). Etude de la phytochimie et des activités biologiques de Zizyphus mauritiana
Lam (Rhamnaceae) utilisée dans le traitement traditionnel $\mathrm{du}$ diabète et de l'hypertension artérielle au Mauritanie.Thèse de Pharmacie FMPOS, Bamako, Mali. 120.

11. Biyiti, L. F., Meko'o, D. J. L., Tamzc, V., \& Amvam Zollo, P. H. (2004). Recherche de l'activité antibactérienne de quatre plantes médicinales camerounaises. Pharm Med Trad Afr, 13,11-20.

12. Hodgson, E. (2004). A textbook of modern toxicology. 3th edition. USA: Wiley Interscience. 525-541.

13. Békro, Y. A., Janat, A., Mamyrbekova, B., Boua, B., Fézan, H., Tra, B., \& Ehouan, E. E. (2007). Étude ethnobotanique et screening phytochimique de Caesalpinia benthamiana (Baill.) Herend. Et Zarucchi (Caesalpiniaceae). Sciences et Nature, 4(2):217-225.

14. Koffi, A. (2003). Valorisation de la pharmacopée africaine : étude toxicologique et pharmacologique de Ziziphus mauritania (Rhamnaceae), une plante réputée anti hypertensive. Thèse de doctorat en pharmacie, Université d'Abidjan Cocody, Abidjan, Côte d'Ivoire. 137.

15. Anonyme. (2008). Pharmacopée européenne, 6eme édition Tome 1,568.

16. Tona, L., Kambu, K., Ngimbi, N., Cimanga, K., \& Vlietinck, A. J. (1998). Antiamoebic and phytochemical screening of some Congolese medicinal plants. J. Ethnopharm, 61, 57-65.

17. Longaga, A., Otshudi, Vercruysse, A., \& Foriers, A. (2000). Contribution to the ethnobotanical, phytochemical and pharmacological studies of traditionally used medicinal plants in the treatment of dysentery and diarrhoea in Lomola area, Democratic Republic of Congo (RDC). Journal Ethnopharmacol, 71, 411-423.

18. OECD (2001). Toxicité orale aiguë - Méthode par classe de toxicité aiguë. Rapport $\mathrm{N}^{\mathrm{o}} 423,14$.

19. OCDE. (2008). Ligne directrice 407 de l'OCDE pour les essais de produits chimiques.

20. Hopkins, W. G. (2003). Physiologie végétale. Traduction de la $2^{\mathrm{e}}$ édition, par Serge Rambour Révision scientifique de Charles-Marie Evrard. 267-283.

21. Ngon Sani, B. (2017). Evaluation de la toxicité aigüe, des activités hypoglycémiantes et anti hyperglycémiantes de l'extrait aqueux de l'écorce du tronc de Musanga cecropioides chez le rat. Thèse Faculté de Médecine et des Sciences Pharmaceutiques de L'Université de Douala, Douala, Cameroun. 77.

22. Ekossono Elle, N. S. (2017). Evaluation de l'activité hypoglycémiante et/ou antihyperglycémiante de l'extrait au vin de palme de la recette de Musanga cecropioides (cecropiaceae) et de Combretum micranthum (Combretaceae) chez les rats. Thèse Faculté de 
Médecine et des Sciences Pharmaceutiques de L'Université de Douala, Douala, Cameroun. 65.

23. Etame Loe, G., Yinyang, J., Okalla Ebongue, C., Makondo, B. V., Ngaba, G. P., Mpondo MPondo E., \& Dibong S. D. (2017). Etude de la toxicité aigüe et subaigüe de l'extrait au vin des graines de Carica papaya Linn. Journal of Applied Biosciences, 120, 12077-12085.

24. Ngo Lemba Tom, E. (2011). Effets antihypertenseurs des extraits de Terminalia superba Englers and Diels (Combretaceae) : étude in vivo et in vitro. Thèse en co-tutelle Université de Yaoundé I et Université de Franche-Comté. 155.

25. Hodge, H. C., \& Stenner J. H. (1943). Deternination of substance acute toxicity by $\mathrm{LD}_{50}$. Am. Ind. Hyg. Assoc., 10, 93-96.

26. Zerriouh, M. (2008). Contribution à l'étude de l'activité antidiabétique de la globularine, un iridoïde isolé des feuilles de Globularia alypum L. chez le rat Wistar. Mémoire de Master Université AbouBekr Belkaib Tlemcen. 67.

27. Sanogo, R., Djimde, A., Guirou, C., Doumbia, L., Maiga, A., Doumbo, O., \& Diallo, D. (2008). Etude de la toxicite sub-chronique du décocté d'Argemone mexicana L. Pharmacopée et Médecine Traditionnelle Africaines, 15, 26-31.

28. Dibong, D. S., Mvogo Ottou, B. P., Vandi, D., Ndjib, C. R., Monkam Tchamaha, F., \& Mpondo Mpondo, E. (2018). Ethnobotanique des plantes médicinales anti hémorroïdaires des marchés et villages du Centre et du Littoral Cameroun. Journal of Applied Biosciences, 96, 9072-9093.

29. Manda, P., Manda, O., Obouo, M., VangahManda, Kroa, E., \& Dano, D. S. (2017). Etude des toxicités aigue et subaiguë du remède Nature utilisé dans le traitement du paludisme. Rev Ivoir Sci Technol, 29,145-158.

30. Wepierre, J. (1981). Abrégé de pharmacologie générale et moléculaire. $2^{\text {eme }}$ édition Masson, Paris. 203. 